\title{
A INCIDÊNCIA DOS DIREITOS FUNDAMENTAIS NAS RELAÇÕES PRIVADAS
}

\author{
RIVA SOBRADO DE FREITAS ${ }^{1}$ \\ ALEXANDRE SHIMIZU CLEMENTE ${ }^{2}$
}

\begin{abstract}
RESUMO: Inseridos no fenômeno denominado "constitucionalização do direito", pelo qual passa grande parte dos ordenamentos jurídicos atuais, os direitos fundamentais, que originalmente foram concebidos para tutelar os indivíduos das freqüentes arbitrariedades estatais, assumem hodiernamente funções protetivas ainda maiores. Em face do aumento das violações dos direitos constitucionais perpetrados, também, pelos sujeitos privados - em especial os detentores de poder econômico ou político - elaborou-se, através da doutrina e jurisprudência, teorias que passaram a admitir a vinculação dos particulares aos direitos fundamentais. A análise dessa nova conjuntura e os efeitos decorrentes da admissibilidade da vinculação dos direitos fundamentais será o escopo do presente trabalho.

PALAVRAS-CHAVE: Direitos Fundamentais; Eficácia; Relações Privadas; Constitucionalização do Direito.
\end{abstract}

ABSTRACT: A part of the phenomenon denominated as "Constitutionalization of Law", which affects most of the current legal systems, fundamental rights, originally conceived as a protection for individuals against the usual State arbitrary action, assume even greater protective functions. In light of the increase on constitutional rights violations, including by private parties - especially those concentrating economic or political power - some theories were developed, by doctrine and jurisprudence, that initiated the idea that private entities are bound by fundamental rights. The analysis of the new conjuncture and the effects resulting from admitting fundamental rights efficacy on Private Law falls within this essay's scope. KEYWORDS: Fundamental Rights; Efficacy; Private Relations; Constitutionalization of Law.

SUMÁRIO: Introdução; 1. A Era da Constitucionalização do Direito; 2. Teorias sobre os efeitos dos Direitos Fundamentais nas Relaç̃es Intersubjetivas; 2.1. Teoria norte-americana da State Action; 2.2. Teoria dos Efeitos Indiretos ou Mediatos;

Artigo recebido em 12.04.2011. Pareceres emitidos em 24.05.2011.

Artigo aceito para publicação em 31.05.2011.

${ }^{1}$ Professora Assistente-Doutor em Direitos Humanos e Direito Constitucional da Universidade Estadual Paulista "Júlio de Mesquita Filho" - UNESP/Franca-SP. Mestre e Doutora pela Pontifícia Universidade Católica de São Paulo (PUC-SP) e Pós-doutora em Direitos Humanos pela Universidade de Coimbra - Portugal. Pesquisadora Líder do Grupo de Pesquisa Constituição e Cidadania - CNPq. rivafreit@ig.com.br

${ }^{2}$ Advogado, bacharel, especialista em Gestão Jurídica da Empresa e Mestrando em Direito pela Universidade Estadual Paulista "Júlio de Mesquita Filho" - UNESP/Franca-SP. Membro integrante do Grupo de Pesquisa Constituição e Cidadania - CNPq. 
2.3. Teoria da Aplicabilidade Direta ou Eficácia Imediata dos Direitos Fundamentais; 3. Direitos Fundamentais e Relações Privadas: O Enfrentamento pela Doutrina e Jurisprudência Brasileira; 3.1. A jurisprudência constitucional da incidência dos Direitos Fundamentais nas relações entre particulares; Conclusão; Referências.

SUMMARY: Introduction; 1 . The Age of the Constituzionalition of Law; 2 . Theories on Fundamental Rights' Effects on Private Relations; 2.1 American State Action doctrine; 2.2. Mediate or Indirect Effects Theory; 2.3. Fundamental Rights' Direct Applicability or Immediate Efficacy Theory; 3. Fundamental Rights and Private Relations: Brazilian Doctrinal and Jurisprudential Approach; 3.1. The Constitutional Jurisprudence on Fundamental Rights' applicability to relations in Private Law; Conclusion; References.

\section{INTRODUÇÃO}

O estudo dos Direitos Fundamentais ganha cada vez mais relevo dentro dos ordenamentos jurídicos ocidentais, especialmente após as atrocidades perpetradas durante as duas grandes guerras mundiais, o que levou a confecção das conhecidas Declarações e Tratados de Direitos Humanos pelos países envolvidos nos conflitos, como por exemplo: a Declaração Universal dos Direitos do Homem (adotada e proclamada pela Resolução 271A (III) da Assembleia Geral das Nações Unidas em 10 de dezembro de 1948), o Pacto Internacional dos Direitos Civis e Políticos e o Pacto Internacional dos Direitos Econômicos, Sociais e Culturais. Como conseqüência deste cenário, presenciamos hodiernamente diversas inovações no âmbito do Direito Constitucional, dentre elas a atualíssima compreensão deste com o Direito Privado surgindo como conteúdo normativo em constante diálogo e intersecção.

Tal fenômeno, conforme demonstraremos, ficou conhecido como a constitucionalização do direito, ou seja, a irradiação das normas e dos valores (do sentimento ${ }^{3}$ ) constitucionais a todos os tecidos do Direito. Sob essa nova perspectiva e paralelamente a sua difusão, notamos a superação da ideia de que os Direitos Fundamentais só se prestariam à tutela dos cidadãos em face do Estado, pois eles enquanto valores essenciais do pacto social firmado passam a ser compreendidos como "postulados sociais", os quais exprimem uma ordem de valores, que se presta a ser fonte de inspiração, impulso e diretriz para a vinculação tanto do processo legislativo, como dos atos da administração pública e também de toda a jurisdição.

\footnotetext{
${ }^{3}$ Cf. O insigne doutrinador espanhol Pablo Lucas VERDU, define com maestria a intrincada questão do "sentimento constitucional" e para tanto se valeu de um estudo multidisciplinar, com o intuito de se definir o que seria o sentimento e após tal desiderato, sua fusão com o direito constitucional e toda cultura política de sua época. Para ele o sentimento constitucional reflete-se no comprometimento dos cidadãos em face das instituições e valores propugnados pela Constituição. Diz VERDU: "Sentir juridicamente é implicar-se com o Direito vigente, com o todo ou com parte dele, dando-lhe apoio. [...] Desse modo, o sentimento jurídico aparece como afeto mais ou menos intenso pelo justo e equitativo na convivência. Quando tal afeto versa sobre a ordem fundamental daquela convivência, temos o sentimento constitucional.". VERDU, Pablo Lucas. O sentimento constitucional: aproximação ao estudo do sentir constitucional como modo de integração política. Rio de Janeiro: Forense, 2004, p. 53.
} 
Nesse sentido, surge na Alemanha, através do trabalho jurisprudencial do Bundesverfassungsgericth ${ }^{4}$, no célebre caso Lüth $^{5}$, a possibilidade de se vincular direitos fundamentais em relações horizontais, ou seja, entre particulares. Conquanto o Tribunal germânico tenha reconhecido e admitido tal vinculação, esta foi a primeira questão a ser enfrentada pela doutrina e jurisprudência, pois já que tais direitos foram criados para regular as relações entre os indivíduos e o Estado, indagava-se de que modo eles deveriam gerar efeitos entre os cidadãos.

Essas questões levaram os estudiosos alemães a se ocuparem por longo tempo na busca de respostas, o que deu origem a essa novel teoria, ou seja, a da constitucionalização do direito, que consequentemente recebeu real destaque e posterior adoção por grande parte da doutrina e jurisprudência de outros países da civil law.

No caso do direito teuto, duas teses se aventaram: a primeira de que os Direitos Fundamentais devem ser aplicados diretamente nas relações entre particulares, tal como é aplicado na relação entre o Estado e o indivíduo; a segunda e que posteriormente preponderou, é a de que os Direitos Fundamentais devem produzir efeitos nas relações intersubjetivas, mas de maneira indireta, ou seja, produzidos, sobretudo, por meio de uma reinterpretação do direito infraconstitucional.

No Brasil, a teoria da constitucionalização do direito é aceita por grande parte dos especialistas ${ }^{6}$, e timidamente pelos magistrados (porém sua aceitação vem sendo paulatinamente incorporada no trato jurisprudencial, inclusive com a sinalização positiva do Supremo Tribunal Federal), isto por que a questão central que o tema coloca não é o problema do "se" os direitos produzem efeitos nessas relações, mas do "como" esses efeitos são produzidos.

A doutrina brasileira ainda não tem uma posição unânime e é neste cenário em construção que o presente trabalho justifica-se. A abordagem do direito comparado e como nossa jurisprudência tem se comportado diante de questões afetas à temática serão objeto da presente investigação.

\section{A ERA DA CONSTITUCIONALIZAÇÃO DO DIREITO}

Pode-se afirmar que a locução Constitucionalização do Direito é um fenômeno recente dentro da dogmática constitucional dos países ocidentais,

\footnotetext{
${ }^{4}$ Tribunal Constitucional Federal alemão.

${ }^{5}$ Sobre o caso Lüth abordaremos seus detalhes e sua importância histórica e dogmática no tópico 2.2.

${ }^{6}$ Nesse sentido, há um grande rol de doutrinadores que se dedicaram ao estudo deste tema, aventando modelos e fortes argumentos para a admissão das teorias que aceitam a vinculação dos particulares aos Direitos Fundamentais. Dentre eles, citaremos os que abordaram diretamente tal questão: SILVA, Virgílio Afonso da. A constitucionalização do direito: os direitos fundamentais nas relações entre particulares. São Paulo: Malheiros, 2005; STEINMETZ, Wilson. Vinculação dos particulares a direitos fundamentais. São Paulo: Malheiros, 2004; SARMENTO, Daniel. Direitos fundamentais e relações privadas. 2. ed. Rio de Janeiro: Lumen Juris, 2008; SARLET, Ingo Wolfgang (org). Constituição, direitos fundamentais e direito privado. 2. ed. Porto Alegre: Livraria do Advogado, 2006.
} 
tanto os da família romano-germânica como os da common law. Num rápido olhar, poderia supor que a expressão pudesse caracterizar, v.g., qualquer arcabouço jurídico no qual se vigorasse uma Constituição dotada de supremacia. Todavia, essa ideia carece de especificidade e não contemplaria todos os seus sentidos. Ela até poderia trazer em si, ademais, o fato de uma Lei Maior incorporar em seu texto inúmeros temas afetos aos ramos infraconstitucionais do Direito.

Contudo, em que pese ser essa uma das facetas deste fenômeno, a noção a ser explorada é, de fato, muito mais ampla. Quer-se demonstrar o efeito expansivo que as normas constitucionais adquiriram, em especial, nos últimos cinquenta anos. Tal difusão centra-se no conteúdo material e axiológico das regras constitucionais, que se reflete com intensa força normativa por todo o sistema jurídico.

Tamanha é a dimensão deste processo expansivo que muitos doutrinadores afirmam que os valores insculpidos na Constituição passaram a condicionar a validade e o sentido de todas as normas infraconstitucionais. Nessa esteira, preleciona José Adércio Leite SAMPAIO:

A força irradiante da Constituição não se limitou apenas à reconstrução dinâmica de seus próprios enunciados (ou fragmentos) de norma numa espécie previsível de auto-alimentação constitutiva, mas se projetou para dentro do sistema jurídico, revisando o seu sistema de fontes e reestruturando continuamente seus pilares concretizante do legislador ordinário, deslizando, em consequência, a primazia (ou a palavra última sobre o sentido da palavra constitucional) em direção ao Judiciário contra os prognósticos modernos.

Percebe-se claramente que um dos efeitos principais deste fenômeno é um "ordenamento jurídico impregnado"8 pelas normas constitucionais, o que faz da Lei Maior um texto invasivo e extremamente expansivo.

A origem desse movimento varia de acordo com a "época constitucional" vivida por cada país. Mas independentemente da Lei Fundamental adotada, certo é que, a constitucionalização ganhou força no pós-guerra, com a proclamação das declarações de proteção ao homem e a consciência que se manifestava na criação de instrumentos para que os cidadãos pudessem se defender de um eventual golpe totalitarista ou restritivo de liberdades. Nos últimos cinquenta anos, percebe-se uma clara difusão e aumento do prestígio das Constituições em diversos ordenamentos jurídicos.

${ }^{7}$ SAMPAIO, José Adércio Leite. Mito e história da constituição: prenúncios sobre a constitucionalização do direito. In: SOUZA NETO, Cláudio Pereira; SARMENTO, Daniel. A constitucionalização do direito: fundamentos teóricos e aplicações específicas. Rio de Janeiro: Lumen Juris, 2007, p. 200.

${ }^{8}$ A expressão é de autoria do professor francês Louis Favoreu e foi empregada no artigo La constitutionnalisation du droit. Cf. FAVOREU, Louis. La constitutionnalisation du droit. In: MATHIEU, Bertrend; VERPEAUX, Michel (org.). La constitutionnalisation des branches du droit. Paris: Economica, 1998. 
Nesse sentido, tomemos como exemplo as Constituições dos Países Ibéricos - Constituição Portuguesa de 1976 e a Espanhola de 1978 elas representam um perfeito modelo do constitucionalismo contemporâneo, ou seja, a Lei Maior não deve mais ficar adstrita a organização do Estado e o estabelecimento do rol dos direitos fundamentais, suas competências extrapolam esse ideário liberal - ela deve, agora, reger grande parte dos aspectos da vida jurídica dos cidadãos e de toda ordem estatal posta, dando a concreta impressão de que quase tudo pode ser objeto das normas constitucionais ${ }^{9}$.

$\mathrm{Na}$ península itálica, o processo de constitucionalização do direito iniciou-se apenas na década de 60, tendo se consolidado, nos anos 70 (mesmo sendo sua Constituição de janeiro de 1948). Tal fato se deve, também pela instalação tardia da Corte constitucional - que ocorreu somente no ano de 1956. Todavia, a partir da sua primeira decisão os direitos fundamentais passaram a ser diretamente aplicáveis, sem a necessária intervenção do legislador.

O trabalho realizado pela Corte Constitucional italiana foi tão importante para a sedimentação desse movimento que suas decisões influenciaram até mesmo o poder legislativo, o qual diante dos posicionamentos por ela assumidos, editaram leis procurando adequar a realidade legislativa aos preceitos magnos. Luís Roberto BARROSO, ao abordar a temática em seu Curso de Direito Constitucional Contemporâneo, narra os fatos ocorridos na Itália:

De 1956 a 2003, a Corte Constitucional proferiu 349 decisões em questões constitucionais envolvendo o Código Civil, das quais 54 declararam a inconstitucionalidade de dispositivos seus, em decisões da seguinte natureza: 8 de invalidação, 12 interpretativas e 34 aditivas. Foram proferidos julgados em temas que incluíram adultério, uso do nome do marido e direitos sucessórios de filhos legítimos, em meio a outros. No plano legislativo, sob influência da Corte Constitucional, foram aprovadas, ao longo dos anos, modificações profundas no direito do trabalho e no direito de família, inclusive em relação ao divórcio e ao regime de adoção. Estas alterações, levadas a efeito por leis especiais, provocaram a denominada "descodificação" do direito civil. ${ }^{10}$

O trabalho da jurisprudência italiana foi corroborado concomitantemente pela doutrina daquele país, que teve em Pietro PERLINGIERI seu principal expoente. Afirma o professor da Università di Camerino: "O papel unificador do sistema, tanto nos seus aspectos mais tradicionalmente civilístico, quanto naqueles de relevância publicista, é desempenhado de maneira cada vez mais incisiva pelo Texto Constitucional." 11 Percebe-se claramente que os

\footnotetext{
${ }^{9}$ Nesse sentido, cf. BON, Pierre. Table ronde: le cas de Espagne. In: VERPEAUX, Michel (org.). Code civil et constitution(s). Paris: Economica, 2005.

${ }_{10}$ BARROSO, Luís Roberto. Curso de direito constitucional contemporâneo: os conceitos fundamentais e a construção do novo modelo. São Paulo: Saraiva, 2009, p. 357-358.

${ }_{11}$ PERLINGIERI, Pietro. Perfis do direito civil: introdução ao direito civil constitucional. 3. ed. Rio de Janeiro: Renovar, 2007, p. 6. Cabe aqui ressaltar que Pietro Perlingieri foi o precursor do
} 
estudiosos italianos acompanharam a tendência jurisprudencial, dando-Ihe amplo resguardo.

Na Alemanha, sob a égide da Lei Fundamental de 1949, o Tribunal Constitucional Federal corroborou o entendimento doutrinário, que já vinha sendo desenvolvido, reafirmando, dessa forma, que os Direitos Fundamentais possuíam um caráter dúplice, ou seja, uma dimensão subjetiva de proteção que abrangia os indivíduos e as associações, além de instituir uma ordem objetiva de valores.

Luís Roberto BARROSO chega a afirmar que o sistema germânico foi concebido para proteger determinados direitos e valores, não apenas pelo eventual proveito que possam trazer a uma ou a algumas pessoas, mas pelo interesse geral da sociedade na sua fruição. Dessa maneira, as normas constitucionais condicionariam a interpretação de todos os ramos do Direito - seja na esfera privada, seja na pública - assim como as funções estatais. Aduz, por último, que o grande precedente nesta matéria foi o caso Lüth, julgado em $1958 .^{12}$

Por fim, mister falar da França, pois seu processo de constitucionalização foi o mais tardio e ainda encontra-se em fase de consolidação. Tal fato se deve, em grande parte, pela adoção particularizada do sistema de controle de constitucionalidade francês, completamente diferente dos mecanismos predominantes (ou seja, o modelo austríaco e o norte-americano), mas que hodiernamente já admite a existência de temas como a chamada impregnação da ordem jurídica pela Constituição.

Louis FAVOREU ${ }^{13}$, doutrinador francês que cuidou de maneira apurada da questão, dividiu, em três estágios o processo de constitucionalização ${ }^{14}$. Para ele em um primeiro momento ocorre a chamada constitucionalizaçãojuridicização, ou seja, a Constituição (lembre-se que o paradigma analisado FAVOREU é o francês) passou a ser lentamente "juridicizada" devido ao trabalho do Conseil Constitutionnel, permitindo que os dispositivos constitucionais passassem a produzir efeitos em todos os demais ramos do ordenamento jurídico.

Numa segunda fase, dar-se-ia a constitucionalização-elevação, que no direito francês corresponderia a um alocamento de matérias na repartição de competências entre as espécies normativas daquele ordenamento

chamado Direito Civil Constitucional e a obra em relevo influenciou decisivamente o desenvolvimento desta corrente no Brasil. Entre nós, merece destaque pelos aprofundados estudos realizados nessa seara, Gustavo Tepedino, Maria Celina Bodin de Moraes, Heloísa Helena Barbosa dentre outros eminentes professores da UERJ.

12 Cf. BARROSO, Luís Roberto. Curso de direito constitucional contemporâneo: os conceitos fundamentais e a construção do novo modelo. São Paulo: Saraiva, 2009, p. 354-355.

${ }^{13} \mathrm{Cf}$. FAVOREU, Louis. La constitutionnalisation du droit. In: AUBY, Jean-Bernard (et al.). L'unité du droit: mélange en hommage à Roland Drago. Paris: Economica, 1996.

${ }^{14} \mathrm{O}$ autor não deixou de modo explícito que tais fases representariam uma ordem progressiva, contudo, parece possível acreditar que cada estágio é requisito sine qua non para o próximo. 
(ou seja, normas constitucionais, leis e o regulamento). De maneira que, muito do que era matéria regulamentar passou a ser reservada a lei e muito do que era do âmbito legal tornou-se matéria constitucional. Esta elevação tem como fim último, a retirada de poder do legislador ordinário, transmitindo esta competência para o Conselho Constitucional.

Por fim, chega-se a chamada constitucionalização-transformação, a qual, segundo FAVOREU é caracterizada pela "constitucionalização dos direitos e liberdades, que conduz a uma impregnação dos diferentes ramos do direito e, ao mesmo tempo, à sua transformação. Mas isso diz respeito também às instituições, especialmente as instituições administrativas e jurisdicionais" ${ }^{\prime 1}$.

Os três estágios traçados por FAVOREU culminam no que ele denominou de efeitos da constitucionalização, os quais passaremos brevemente a resumir. O primeiro deles é a unificação da ordem jurídica pela qual as normas constitucionais tornam-se progressivamente o fundamento comum dos diversos ramos do direito, ademais, este efeito gera, ainda, a relativização da dicotomia direito público e privado.

O segundo efeito do fenômeno descrito por FAVOREU seria a simplificação da ordem jurídica, pois uma decorrência direta da constitucionalização do direito seria o rearranjo da Constituição como inegável norma de referência do ordenamento jurídico.

Nota-se, com o pensamento de Louis FAVOREU que a constitucionalização do direito é um fato inegável e um processo constante, pelo qual passa, em grande medida, os atuais ordenamentos jurídicos. A constitucionalizaçãotransformação sintetiza a problemática deste trabalho, pois ao se admitir a constitucionalização dos direitos e liberdades, bem como, a constitucionalização dos demais ramos do direito, pode-se deduzir que os Direitos Fundamentais passam, inegavelmente, a se vincular também dentro do direito privado, invadindo até mesmo as relações entre os particulares.

Todavia, este processo não pode ser visto sem reservas, sob pena de se perder a autonomia mínima necessária dos demais ramos do direito, pois, cada um deles possui suas idiossincrasias inerentes as suas funções dentro do ordenamento. Nesse sentido, magistral a lição, a seguir transcrita, proferida por Eugênio FACCHINI NETO:

No mesmo diapasão, há muito tempo [...] Ludwig Raiser sustentou a necessidade de o direito privado não perder sua especificidade, ainda que sofrendo o influxo das opções valorativas do legislador constituinte. Isto porque "o direito privado torna possível a múltipla diferenciação da e na sociedade, constituindo um precioso contrapeso ao asssistencialismo e reforçando, com seus instrumentos, o sentido de auto-responsabilidade do indivíduo, oferecendo, com isso, uma preciosa contribuição à democracia. Portanto, é necessário realizar uma sociedade fundada

\footnotetext{
${ }^{15}$ Cf. FAVOREU, Louis. La constitutionnalisation du droit. In: AUBY, Jean-Bernard (et al.). L'unité du droit: mélange en homage à Roland Drago. Paris: Economica, 1996, p. 37.
} 
sobre o direito privado que não seja nem separada e nem absorvida pelo Estado, mas que esteja a ele integrada, garantindo-se sua autonomia, em um sistema vinculado à Lei Fundamental". ${ }^{16}$

De maneira que, feita esta ressalva imperiosa - pela qual nos filiamos devemos encarar o fenômeno como contínuo e irreversível. Entretanto, acreditamos que além dos efeitos, citados por FAVOREAU, a constitucionalização do direito promove outro (considerado ainda muito mais importante) qual seja, a vinculação das relações entre particulares a direitos fundamentais.

Percebe-se, finalmente, a superação da visão liberal, pela qual os Direitos Fundamentais só deveriam produzir efeitos na relação entre o Estado e os cidadãos. Esta limitada concepção, acompanhando o fenômeno da constitucionalização, reconheceu que na hodierna sociedade nem sempre é o Estado o maior corruptor dos Direitos fundamentais, pois, este posto muitas vezes é ocupado por particulares, principalmente aqueles dotados de algum poder social ou econômico.

Contudo, aceitar a vinculação é apenas o passo inicial que a doutrina enfrenta ao desenvolver teorias, as quais se propõem a elaborar um modelo para a aplicação dos Direitos Fundamentais nas relações entre os particulares. Muitas são as consequências e as dificuldades de se transportar uma racionalidade que tinha originalmente como destinatário dos direitos fundamentais o Estado, para uma nova relação, na qual as duas partes envolvidas (ou seja, os particulares) são, também, titulares desses mesmos direitos.

Assim sendo, superada a questão da irradiação dos efeitos dos Direitos Fundamentais (como consequência da constitucionalização) para todos os ramos do Direito, promovendo inclusive a vinculação daqueles aos particulares, voltaremos nossa análise para as teorias que se ocuparam a regular a incidência desta vinculação. Abordaremos, ainda que de maneira sucinta, duas grandes correntes teóricas, divididas entre aqueles ordenamentos que não aceitam a vinculação (tal negação é apenas aparente, trata-se na verdade de um artifício usado para não se olvidar da tradição liberal), frente aos que a admitem, sendo certo que esta se subdivide em duas linhas, ou seja, os que propugnam que os Direitos Fundamentais tenham uma aplicabilidade indireta (ou eficácia mediata) e, por outro lado, aqueles que defendem a aplicabilidade direta (eficácia imediata) dos jusfundamentais nas relações privadas.

2. TEORIAS SOBRE OS EFEITOS DOS DIREITOS FUNDAMENTAIS NAS RELAÇÕES INTERSUBJETIVAS

No tópico anterior, ressaltamos a importância do fenômeno da constitucionalização do direito e como seus efeitos irradiadores importaram

${ }^{16}$ FACCHINI NETO, Eugênio. Reflexões histórico-evolutivas sobre a constitucionalização do direito privado. In: SARLET, Ingo Wolfgang (org.). Constituição, Direitos Fundamentais e Direito Privado. 2. ed. Porto Alegre: Livraria do Advogado, 2006, p. 48. 
na aceitação do atrelamento dos Direitos Fundamentais entre os particulares. E tal fato é de suma importância em uma sociedade tão desigual quanto a brasileira, em que o Estado, paralelamente a diversos atores, é apenas um dos sujeitos opressores no convívio social.

Porém, como ressaltado alhures, não é tão fácil transferir um mecanismo originalmente criado para disciplinar uma relação entre um cidadão e o Estado, para uma relação em que os dois figurantes sejam titulares de Direitos Fundamentais.

Sendo assim, uma das dificuldades enfrentadas por aqueles que se dedicaram ao assunto (para não dizer a maior delas), foi a conciliação da tutela efetiva dos Direitos Fundamentais - tendo em vista que as situações de desrespeito provem de todos os lados - e a salvaguarda da autonomia privada. Essa problemática, a qual já havíamos tangenciado, é de elevada acuidade e vai definir os parâmetros das teses que enfrentaram a questão dos efeitos da vinculação dos Direitos Fundamentais.

Destarte, passaremos a abordar as correntes que se ocuparam em criar modelos eficientes para o controle dos efeitos dessa incidência constitucional, não obstante, de imediato, versaremos sobre a tese que nega (ainda que de modo aparente e artificial) a eficácia dos Direitos Fundamentais nas relações subjetivas, a chamada Doutrina estadunidense da State Action.

\subsection{Teoria norte-americana da State Action}

Conforme afirmamos anteriormente, a State Action Doctrine apresenta como característica principal a negação, prima facie, da possibilidade de vinculação dos Direitos Fundamentais nas relações privadas. Todavia, trata-se de uma rejeição aparente, pois, como ficará demonstrado, a jurisprudência norte-americana, se vale de subterfúgios para não reconhecer a incidência direta dos Direitos Fundamentais entre os indivíduos - para assim se manter fiéis a tradição liberal daquele país. Este fato nos leva a acreditar que esta teoria só poderia encontrar guarida nos Estados Unidos, pois sua Constituição é, nos dizeres de Wilson STEINMETZ, a mais genuína expressão do paradigma constitucional liberal ${ }^{17}$.

O artifício encontrado pelos pensadores norte-americanos consistia em imputar ao Estado a responsabilidade por atos privados ou em equipará-los a atos estatais. Dessa forma, não aceitando expressamente a vinculação dos particulares, pode-se, chegar a um resultado equiparável às teorias que aceitam a produção de efeitos em face da incidência dos Direitos Fundamentais.

Portanto, a State Action Doctrine tem uma meta audaciosa e concomitantemente complexa, ou seja, definir em quais situações uma conduta privada estará vinculada as disposições de Direitos Fundamentais. Com este objetivo, ela procura romper com a limitada concepção de que os

17 STEINMETZ, Wilson. Vinculação dos Particulares a Direitos Fundamentais. São Paulo: Malheiros, 2004, p. 181. 
Direitos Fundamentais só poderiam ser opostos em face do Estado e tenta definir, ainda que de forma assistemática (diante da ausência de um modelo específico) e casuística - o que é natural em um país de common law, baseado no sistema de precedentes - quando uma ação privada pode ser comparada ou mesmo convertida a uma ação pública.

Esta equiparação é exatamente o tal ardil acima referido, e visa transformar um ato privado - transgressor de Direitos Fundamentais, em ato público, para então poder agir e, de maneira indireta reconhecer que as relações interpessoais, também estão submetidas aos Direitos Fundamentais.

Em que pese a teoria da State Action querer negar (ainda que aparentemente) a vinculação dos Direitos Fundamentais, o trabalho jurisprudencial da Suprema Corte estadunidense acaba encontrando, de uma forma ou de outra, uma conformação daquela ação privada, transformando-a em pública, garantindo, desse modo, que se preserve um direito constitucional violado. Nesse sentido, a análise do caso Shelley v. Kramer ${ }^{18}$ revela o uso dos subterfúgios pela jurisprudência norte-americana, com o claro intuito de converter um ato privado em estatal. O caso se passou na cidade de Saint Louis onde em um loteamento local, exigia-se que os proprietários daqueles terrenos não os alienassem a pessoas negras. Todavia, um casal ao vender sua casa, o fez para afrodescendentes, o que incitou os demais moradores a ajuizarem a ação pedindo a anulação do negócio. A demanda foi considera procedente em todas as instâncias inferiores, contudo, a Suprema Corte, contrariamente, decidiu pela nulidade da cláusula e, consequentemente, a validade da compra e venda.

Os magistrados norte-americanos ao fundamentarem sua decisão, não o fizeram tendo em vista a Emenda XIV (garantia dos direitos civis), mas sim com base no julgamento proferido pelas instâncias inferiores (ato estatal), pois seria inadmissível que o Estado coadunasse com uma situação claramente discriminatória, o que ensejou, portanto, na decretação da nulidade da cláusula restritiva.

Nota-se, com esta decisão paradigmática - a primeira de muitas outras proferidas pela Suprema Corte, sempre nesse mesmo sentido - que de certo modo, a jurisprudência caminha em sentido diverso com a doutrina. Este fato é ressaltado por Virgílio Afonso da Silva, em sua obra, quando ele assevera:

Por isso, ainda que se insista [em especial a doutrina] que, nos Estados Unidos, os direitos fundamentais somente vinculem as autoridades estatais, a prática jurisprudencial tem mostrado uma outra realidade, ainda que encoberta: a de que os direitos fundamentais vinculam, de alguma forma, os indivíduos nas suas relações entre si.

Uma análise quantitativa da jurisprudência da Suprema Corte norte-americana - como a levada a cabo por Thomas Giegerich - pode

${ }^{18}$ Cf. 334 US 1 (1948), apud SARMENTO, Daniel. Direitos Fundamentais e Relações Privadas. 2. ed. Rio de Janeiro: Lumen Juris, 2008, p. 192. 
fornecer ainda mais indícios para a tese aqui sustentada, segundo a qual a Corte, quando pretende coibir um ato privado violador de direitos fundamentais, encontra algum artifício para equipará-lo a um ato público. ${ }^{19}$

A guisa de conclusão, podemos afirmar que mesmo em face da forte tradição liberal nos Estados Unidos, a possibilidade da incidência dos Direitos Fundamentais nas relações entre particulares (ainda que seja valendo-se de estratagemas) é uma realidade, e tal fato se deve, em grande medida ao trabalho pioneiro e vanguardista da Suprema Corte daquele país.

\subsection{Teoria dos Efeitos Indiretos ou Mediatos}

O escopo neste tópico é apresentar a Teoria dos Efeitos Indiretos ou Mediatos, evidenciando seu surgimento, suas principais características, os países que a adotaram bem como tecer algumas críticas em seus pontos mais controvertidos. De início, cumpre ressaltar que esta tese é uma construção intermediária entre aquela que negam a vinculação (State Action) e a que sustenta a eficácia direta ou imediata dos efeitos dos direitos fundamentais na esfera privada.

Originalmente desenvolvida na Alemanha, por Günter DÜRIG ${ }^{20}$, a chamada Mittelbare Drittwirkung, tornou-se a concepção dominante e hodiernamente é adotada por grande parte da doutrina, e em grande medida, também pelo Tribunal Constitucional Alemão.

Por esta tese, deve-se, prioritariamente reconhecer um direito geral de liberdade - sacramentado por grande parte dos ordenamentos constitucionais do ocidente - pelo qual se vai buscar um equilíbrio entre os Direitos Fundamentais de um lado, e a autonomia do Direito Privado, de outro, impedindo assim, uma total dominação do direito constitucional sobre o privado.

Nesse sentido, DÜRIG elabora uma proposta, pela qual sugere que a incidência dos Direitos Fundamentais nas relações privadas se dê por intermédio do material normativo do próprio direito privado, ou seja, através das cláusulas gerais e dos conceitos indeterminados. Seria necessário, segundo o doutrinador alemão, a construção de certas "pontes" entre o Direito Privado e a Constituição, com o intuito de submeter aquele aos valores constitucionais.

Nesse diapasão, os Direitos Fundamentais representariam uma ordem objetiva de valores ou ainda um sistema de valores, fazendo com que seus efeitos irradiadores sejam sentidos em todos os ramos do ordenamento jurídico. No Direito Privado, esses valores (ou seja, os Diretos Fundamentais) adentram a esfera privada, através das cláusulas gerais e dos conceitos indeterminados ${ }^{21}$.

\footnotetext{
${ }^{19}$ SILVA, Virgílio Afonso da. A constitucionalização do direito: os direitos fundamentais nas relações entre particulares. São Paulo: Malheiros, 2005, p. 102.

${ }^{20}$ Cf. DÜRIG, Günter. Grundrechte und Zivilrechtsprechung. In: MAUNZ, Theodor (org.). Vom bonner grundgesetz sur gezamtdeustschen verfassung: festschrift zum 75. Geburtstag von Hans Nawiasky. Munique: Isar, 1956.

${ }^{21}$ No ordenamento jurídico brasileiro, podemos citar como exemplos de cláusulas gerais, as seguintes disposições do Código Civil: art. 187: as locuções fim econômico e social, boa-fé e
} 
Devemos ressaltar ainda, que para os adeptos dessa teoria, não basta apenas essa construção teórica, na qual os Direitos Fundamentais representam uma ordem objetiva de valores e que vão irradiar seus efeitos através das chamadas "pontes" fundadas no substrato do Direito Material. A aplicação dessa teoria envolve uma conjugação de esforços de todas as funções estatais, pois somente assim ela terá êxito em vincular os particulares aos direitos fundamentais sem, contudo, obrigá-los a abrir mão da autonomia da vontade.

Ulterior a todo o exposto, é necessário a tarefa de mediar a aplicação dos direitos fundamentais sobre os particulares, função esta que cabe exclusivamente ao legislador ordinário, pois, cumpre a ele estabelecer, uma disciplina que se demonstre compatível com os valores constitucionais. Noutras palavras: compete, portanto, ao legislador, a função de proteger os direitos fundamentais sem permitir que estes ultrapassem a autonomia da vontade.

Ao Judiciário cumpriria preencher as cláusulas gerais com os com o substrato axiológico dos direitos fundamentais, posto que são eles a representação de uma ordem objetiva de valores. Porém, sua tarefa não se encerra por aí. É sua atribuição, ainda, rejeitar peremptoriamente a aplicação de normas de direito privado, caso estejam eivadas de inconstitucionalidade.

Cumpre agora destacar, o papel dessa teoria junto a jurisprudência alemã, pois, o célebre caso Lüth foi o ponto de partida para a elaboração das teses sobre a vinculação dos Direitos Fundamentais nas relações privadas.

Erich Lüth era presidente de uma associação de imprensa e durante uma conferência que reunia diversos produtores de filmes cinematográficos, defendeu abertamente o boicote às películas de Veit Harlan, visto que durante o período nazista, tal diretor havia dirigido filmes propagandísticos do regime. Inconformado com a censura, Harlan ajuizou uma ação indenizatória, e teve seu pedido reconhecido pelas instâncias inferiores. Lüth então recorreu ao Tribunal Constitucional Alemão, que anulou as decisões favoráveis a Harlan, sustentando que elas feriam a livre manifestação do pensamento de Lüth.

A decisão não teve como fundamento o direito a manifestação do pensamento, mas sim em uma exigência do $\S 826^{22}$ do BGB alemão, especialmente a alusão do conceito de bons costumes. Acreditamos ser oportuno transcrever um trecho da decisão que reflete a fundamentação ora apresentada:

A influência dos direitos fundamentais, como critérios valorativos, se realiza sobretudo mediante aquelas disposições do direito privado que contêm direito imperativo e portanto formam parte da ordem pública em sentido amplo, isto é, mediante os princípios que por razões

bons costumes; no art. 113: novamente a presença da boa-fé, desta vez na seara dos negócios jurídicos e art. 13: a disposição do próprio corpo que contrarie os bons costumes etc.

${ }_{22}$ Dispõe o § 826 do BGB: "Quem causar danos a outra pessoa de forma contrária aos bons costumes fica obrigado a indenizá-los". 
de interesse geral, hão de ser vinculantes para a modelação das relações jurídicas entre os particulares e portanto, estão subtraídos à autonomia da vontade. Tais disposições, por sua finalidade, estão casadas com o direito constitucional. Para realização dessa influência, à jurisprudência são oferecidas sobretudo as "cláusulas gerais" que, como a do § 826, BGB, remetem, para o juízo da conduta humana as medidas metacivis e inclusive metajurídicas. No momento de decidir 0 que esses mandatos sociais exigem no caso concreto há de partir-se, em primeiro lugar, da totalidade das representações de valor que o povo alcançou em um determinado momento do seu desenvolvimento cultural e fixado em sua Constituição. Por isso, se tem qualificado com razão as cláusulas gerais como os "pontos de irrupção" (Einbruchtstellen) dos direitos fundamentais no direito civil. ${ }^{23}$

Pela leitura do excerto, fica claro o uso da chamada "cláusula geral" como fundamento da decisão. Valendo-se da teoria da eficácia mediata, o Tribunal Constitucional não utilizou diretamente a Lei Fundamental, mas sim o disposto no $\S 826$, tido pela doutrina como uma porta de entrada para os Direitos Fundamentais, e como bem observado por Virgílio Afonso da SILVA, seja para anular decisões que não os tenha levado em conta, seja para extirpar relações jurídicas que o ofendam, a ideia de bons costumes, foi reinterpretada à luz dos valores constitucionais. ${ }^{24}$

Por fim, resta destacar as críticas aventadas a teoria dos efeitos indiretos. As principais delas dizem respeito, em primeiro lugar, a noção de direitos fundamentais enquanto ordem objetiva de valores. $O$ ataque neste argumento assume capital importância, pois ele atinge a base da construção da tese, ou seja, sem a ideia de direitos fundamentais enquanto um sistema de valor, não há como colocá-la em prática. Nesse sentido, os críticos apontam que os valores não impõem deveres incondicionais e inequívocos, ao contrário, eles concorrem por preferências, logo estão sob constante tensão e podem ser configurados de maneira flexível, ameaçando o princípio da segurança jurídica.

Em segundo plano, os ataques se voltam para a insuficiência de cláusulas gerais e nesse sentido, afirmam que seria difícil imaginar que todas as cláusulas previstas na legislação civil, poderiam ser sempre suficientes para servir como ponte entre os direitos fundamentais e o material normativo do direito privado. De maneira que, muitas situações poderiam ficar desprotegidas e entregues a própria sorte.

E como última crítica, ventila-se o caráter supérfluo da construção, pois ela pode ser reconduzida inteiramente a noção de interpretação conforme a constituição.

${ }^{23}$ BVerfGE 7, 198 apud. GARCÍA TORRES, Jesús; JIMÉNEZ-BLANCO, Antonio. Derechos fundamentales y relaciones entre particulares. Madrid, Civitas, 1986, p. 29-30.

${ }^{24}$ SILVA, Virgílio Afonso da. A constitucionalização do direito: os direitos fundamentais nas relações entre particulares. São Paulo: Malheiros, 2005, p. 80-81. 


\subsection{Teoria da Aplicabilidade Direta ou Eficácia Imediata dos Direitos} Fundamentais

Abordaremos agora a tese que defende a aplicação direta ou, ainda, a eficácia imediata dos Direitos Fundamentais entre os particulares. Quando se usa essa expressão aplicabilidade direta quer com ela dizer que, que os Direitos Fundamentais serão aplicados nas relações entre particulares, tal qual eles são utilizados nas interconexões com o Estado, isto é, não será necessário nenhum tipo de ação intermediária (mediação legislativa ou artifícios).

De origem germânica, a Teoria da Aplicabilidade Direta foi desenvolvida por Hans Carl NIPPERDEY ${ }^{25}$, nos anos 50, o qual defendia, em suma, que os Direitos Fundamentais apresentavam um caráter dúplice, pois, alguns vinculariam apenas o Estado e outros poderiam ser invocados - diretamente - nas relações particulares, independente de mediação legislativa.

Contudo, seu pensamento não encontrou muitos adeptos em seu país. Apenas o Tribunal Federal do Trabalho em decisões pontuais adotou a tese da aplicabilidade direta, como noticia Daniel SARMENTO, em 1957 a Corte trabalhista reconheceu diretamente, com base em preceitos constitucionais sem a invocação de nenhum dispositivo de direito privado e tão pouco da legislação laboral - a invalidade de cláusula contratual que previa a extinção do contrato de trabalho de enfermeiras de um determinado hospital, caso estas viessem a contrair matrimônio. ${ }^{26}$

A grande diferença, portanto, dessa teoria para a Tese dos Efeitos Indiretos é possibilidade dos Direitos Fundamentais produzirem seus efeitos sem a necessidade de pontes ou portas de entradas oriundas do Direito Privado, pois para NIPPERDEY, aqueles se constituem verdadeiros direitos subjetivos dos particulares em suas relações. Sendo assim, isso leva a imperiosa conclusão que em termos concretos, podem os indivíduos recorrerem aos direitos fundamentais para fazê-los valer contra outros particulares.

Cumpre destacar, ainda, que os adeptos a esta teoria não ignoram a existência de especificidades na sua aplicação e, portanto, diante de um caso concreto, reconhecem a necessidade de ponderação entre o direito fundamental e a autonomia privada dos indivíduos envolvidos na relação.

Contudo, em que pese esta tese não ter sido predominante na Alemanha, ela influenciou de forma decisiva, muitos outros países da Europa e tem sido o entendimento dominante em Espanha, Portugal, Itália, bem como é a posição esposada pela grande parte dos doutrinadores brasileiros. Ousaríamos dizer que o próprio Supremo Tribunal Federal se coaduna a esta corrente.

\footnotetext{
${ }^{25}$ Cf. NIPPERDEY, Hans Carl. Grundrechte und privarecht. In. NIPPERDEY, Hans Carl (org.). Festschrift für Erich Molitor zum 75. Geburtstag. Munique: C.H. Beck, 1962.

${ }^{26}$ SARMENTO, Daniel. Direitos Fundamentais e Relações Privadas. 2. ed. Rio de Janeiro: Lumen Juris, 2008, p. 205.
} 
Os reflexos dessas teorias na jurisprudência nacional serão analisados oportunamente, onde teceremos maios reflexões acerca da temática. ${ }^{27}$

Tal qual a tese desenvolvida por Günter DÜRIG, esta também não ficou isenta de árduas críticas. A primeira, aventada pelos defensores da Teoria dos Efeitos Indiretos, diz respeito a perda de identidade do Direito Privado em face da hipertrofia dos Direitos Fundamentais. Nos dizeres de Claus-Wilhelm CANARIS:

Ela [a relação entre os direitos fundamentais e o Direito Privado] radica no fato de os direitos fundamentais, enquanto parte da Constituição, terem um grau mais elevado na hierarquia das normas do que o Direito Privado, podendo, por conseguinte, influenciá-lo. Por outro lado, a Constituição, em princípio, não é o lugar correto nem habitual para regulamentar as relações entre cidadãos individuais e entre pessoas jurídicas. Nisso consiste, muito pelo contrário, a tarefa específica do Direito Privado, que desenvolveu nesse empenho uma pronunciada autonomia com relação à Constituição; e isso não vale apenas em perspectiva histórica, mas também no tocante ao conteúdo, pois o Direito Privado, em regra, disponibiliza soluções muito mais diferenciadas para conflitos entre os seus sujeitos do que a Constituição poderia fazer. ${ }^{28}$

Todavia, hodiernamente a corrente da aplicabilidade direta já é vista com maiores temperamentos e os doutrinadores buscam modelos que visam a adequação desta complexa situação, ou seja, busca-se uma melhor modulação dos efeitos dos Direitos Fundamentais frente a autonomia privada - princípio basilar do Direito Privado.

Uma segunda objeção diz respeito a constitucionalização dos conflitos entre os particulares e o suposto caos que essa situação poderia provocar diante da Jurisdição Constitucional. Esta crítica possui certa relevância nos ordenamentos em que o sistema de controle de constitucionalidade é concentrado. Nesses países certamente haverá um maior esforço dos doutrinadores para dar soluções processuais a esta intrincada questão. Todavia, se analisarmos esta situação no âmbito do controle de constitucionalidade brasileiro, ela perde sentido, pois em face do controle difuso, tais questões poderão ser apreciadas pelo juiz singular, sem a necessidade da questão ser apreciada por uma Corte Constitucional.

Por fim, questiona-se a simples transposição da relação dantes exercida em face do Estado para a relação indivíduo versus indivíduo. Argumentam os críticos que essa simples transposição foi pensada de maneira muito simplista e não se observou os pontos críticos e peculiaridades nessa nova configuração relacional. Porém todos os modelos propostos possuem como ponto central a tensão entre a autonomia privada, de um lado e os direitos

\footnotetext{
${ }^{27}$ Cf. 3.1.

${ }^{28}$ CANARIS, Claus-Wilhelm. A influência dos direitos fundamentais sobre o direito privado na Alemanha. In: SARLET, Ingo Wolfgang (org). Constituição, Direitos Fundamentais e Direito Privado. 2. ed. Porto Alegre: Livraria do Advogado, 2006, p. 227.
} 
fundamentais, de outro, ou seja, o traço distintivo nesta novel relação particular - particular. Nesse sentido, a busca por uma sistematização pela qual se observa necessariamente essa questão, certamente é um quesito obrigatório da pauta daqueles que ainda se dedicam ao assunto.

Apresentada esta Teoria que, como afirmado alhures é que certamente encontra mais adeptos na doutrina brasileira, parece oportuno citar as principais teses desenvolvidas entre nós, as quais levam em consideração o ordenamento jurídico nacional (imbuído em um paradigma constitucional socialdemocrático), o que impõe, de certa maneira, um modelo exclusivo que visa atender as demandas particularizadas de nossa sociedade.

\section{DIREITOS FUNDAMENTAIS E RELAÇÕES PRIVADAS: $O$} ENFRENTAMENTO PELA DOUTRINA E JURISPRUDÊNCIA BRASILEIRA

A dogmática brasileira dos Direitos Fundamentais conta hoje com três excelentes obras que visam, em última análise, delimitar modelos ou standards adequados, para orientar a aplicação jurisprudencial nas questões afetas a vinculação dos direitos fundamentais nas relações privadas, almejando suprir a subjetividade das decisões, conferindo maior segurança e previsibilidade no trato destas questões.

Nesta etapa do trabalho, analisaremos os modelos propostos por Daniel SARMENTO ${ }^{29}$, Wilson STEINMETZ ${ }^{30}$ e Virgílio Afonso da SILVA ${ }^{31}$, demonstrando criticamente os aspectos principais das teorias desenvolvidas por cada autor. De modo geral, todos eles se filiam a tese dos efeitos diretos divergindo, entretanto, na maneira de se proceder a vinculação direta. Ao cabo dessa tarefa, apresentaremos o panorama da questão aos olhos da jurisprudência constitucional, destacando alguns julgados do STF que tangenciam e outros que tratam efetivamente sobre questão da vinculação dos Direitos Fundamentais as relações privadas.

Daniel SARMENTO, em sua obra Direitos fundamentais e relações privadas, buscou resolver a tensão entre os Direitos Fundamentais e a Autonomia Privada, valendo-se de dois conceitos principais: o primeiro a dicotomia simetria-assimetria das partes e o segundo, com inspiração em Pietro PERLINGIER ${ }^{32}$, questões existenciais/patrimoniais.

\footnotetext{
${ }^{29}$ Cf. SARMENTO, Daniel. Direitos Fundamentais e Relações Privadas. 2. ed. Rio de Janeiro: Lumen Juris, 2008.

${ }^{30}$ Cf. STEINMETZ, Wilson. Vinculação dos Particulares a Direitos Fundamentais. São Paulo: Malheiros, 2004.

${ }^{31}$ Cf. SILVA, Virgílio Afonso da. A constitucionalização do direito: os direitos fundamentais nas relações entre particulares. São Paulo: Malheiros, 2005.

${ }^{32}$ Cf. PERLINGIERI, Pietro. Perfis do direito civil: introdução ao direito civil constitucional. 3. ed. Rio de Janeiro: Renovar, 2007. Em especial os capítulos sétimo e oitavo. No capítulo sétimo qual o professor italiano delimita as chamadas questões subjetivas existências, fundadas no art. $2^{\circ} \mathrm{da}$ Constituição Italiana (A República reconhece e garante os direitos invioláveis do homem, já seja como indivíduo, já seja nas formações sociais onde se desenvolve sua personalidade, e exige o cumprimento dos deveres inderrogáveis de solidariedade política, econômica e social), já no capítulo oitavo descreve as relações provenientes das situações subjetivas patrimoniais.
} 
O primeiro critério é tido, por ele, como primordial, pois através dele se entende que essa dicotomia funda-se na desigualdade fática (material) dos indivíduos. Para SARMENTO, "a assimetria de poder numa determinada relação tende a comprometer o exercício da autonomia privada da parte mais fraca, expondo a um risco maior seus direitos fundamentais"33. Quanto ao segundo critério, o enfoque se volta as questões existenciais ou patrimoniais, nesse sentido, assevera o autor que se a controvérsia for acerca de questões existenciais, deve-se prevalecer os direitos fundamentais, por outro lado, se estiver em jogo uma questão patrimonial, deverá ser respeitada a autonomia privada.

O modelo de SARMENTO é de fato muito coerente e se adapta a realidade jurídica e social brasileira. Contudo, quando o autor funda um dos seus conceitos chaves na questão da desigualdade material, abre margens para que o subjetivismo do julgador aflore e favoreça situações injustas, pois, a chamada desigualdade material é um conceito estanque e pressupõe que em situações nas quais ela estiver presente, sempre o hipossuficiente deverá ter, necessariamente, maior proteção. Quanto ao segundo critério, SARMENTO encontra uma brilhante solução para equacionar a tensão entre autonomia privada e a incidência dos direitos fundamentais.

Em $A$ vinculação dos particulares a direitos fundamentais, Wilson STEINMETZ, constroi uma proposta valendo-se do princípio da proporcionalidade (aos moldes de ALEXY $^{34}$ ) para superar a tensão existente entre a autonomia da vontade e os Direitos Fundamentais. Propõe, ainda, um modelo, com o uso das chamadas precedência prima facie (novamente sob inspiração de Robert ALEXY), que segundo ele:

Não contêm determinações definitivas em favor de um princípio [...] contudo estabelecem um ônus de argumentação para a precedência do outro princípio no caso concreto. Assim uma precedência prima facie constitui uma carga de argumentação a favor de um princípio e, por consequência, uma carga de argumentação contra o outro princípio. De um lado, essas precedências não estabelecem determinações definitivas; de outro, exigem o cumprimento ou a satisfação de um ônus de argumentação para serem afastadas. ${ }^{35}$

Transportando essa construção para o embate existente entre autonomia privada versus direitos fundamentais, STEINMETZ vai desenvolver quatro precedências prima facie, a seguir transcritas:

\footnotetext{
${ }^{33}$ SARMENTO, Daniel. Direitos Fundamentais e Relações Privadas. 2. ed. Rio de Janeiro: Lumen Juris, 2008, p. 329.

${ }^{34}$ Tanto Wilson STEINMETZ, quanto Virgílio Afonso da SILVA, vão se valer dos conceitos elaborados por Robert Alexy na seguinte obra: ALEXY, Robert. Teoria dos Direitos Fundamentais. São Paulo: Malheiros, 2008.

${ }_{35}$ STEINMETZ, Wilson. Vinculação dos Particulares a Direitos Fundamentais. São Paulo: Malheiros, 2004, p. 215.
} 
1. Em uma relação contratual de particulares em situação (ou sob condições) de igualdade fática, há uma precedência prima facie do direito fundamental individual de conteúdo pessoal ante o princípio da autonomia privada.

2. Em uma relação contratual de particulares em situação (ou sob condições) de desigualdade fática, há uma precedência prima facie do direito fundamental individual de conteúdo pessoal ante o princípio da autonomia privada.

3. Em uma relação contratual de particulares em situação (ou sob condições) de igualdade fática, há uma precedência prima facie do princípio da autonomia privada ante o direito fundamental individual de conteúdo patrimonial.

4. Em uma relação contratual de particulares em situação (ou sob condições) de desigualdade fática, há uma precedência prima facie do direito fundamental individual de conteúdo patrimonial ante o princípio da autonomia privada. ${ }^{36}$

O ponto nevrálgico de sua teoria fica adstrito ao uso do princípio da proporcionalidade para solucionar problemas nos quais a figura estatal não participa, tendo em vista que, a proporcionalidade só poderá ser aplicada em situações nas quais o Estado se faz presente. Exemplifiquemos, para se valer do princípio da proporcionalidade deve-se observar a regra tríade, ou seja, a adequação, a necessidade e a proporcionalidade em sentido estrito. Como conciliar, por exemplo, a regra da adequação, em uma relação contratual entre particulares. Certamente não há como exigir de um particular, em um caso concreto de restrição de direitos fundamentais, que ele adote as medidas estritamente necessárias, ou seja, menos gravosas para atingir seu fim perseguido, sem que isso lhe retire, por completo, a autonomia da livre disposição contratual.

Outro ponto passível de questionamentos na teoria de STEINMETZ é o recurso a chamada desigualdade material nos mesmos moldes propostos por SARMENTO. As observações realizadas na tese do professor carioca, também se enquadram para o modelo de STEINMETZ.

Por último, cumpre analisar a proposta de Virgílio Afonso da SILVA. Em seu livro, $A$ constitucionalização do direito: os direitos fundamentais nas relações entre particulares, após uma minuciosa e crítica análise, de grande parte dos desenvolvimentos teóricos sobre o assunto, o professor paulista propõe um Modelo Diferenciado que, em suma, seria capaz de enquadrar mais os diversos tipos de situações em que os direitos fundamentais produziriam efeitos entre os particulares.

SILVA propõe um standard baseado em conceitos de Robert ALEXY. Para ele, a ideia de que os Direitos Fundamentais representam uma ordem objetiva de valores não tem sentido diante de uma Carta Constitucional como

${ }^{36}$ STEINMETZ, Wilson. Op. cit. p. 224. 
a nossa, pois ela traz em seu bojo, um rol exaustivo de direitos, o que garante, em grande medida, maior segurança jurídica. Contudo, para que esses direitos se irradiem por todo o ordenamento (inclusive para as relações privadas), se faz mister encará-los como princípios (ou seja, normas que exigem que algo seja realizado na maior medida possível diante das possibilidades fáticas e jurídicas existentes ${ }^{37}$ ) e, por conseguinte como mandamentos de otimização. A partir daí, a tarefa será como controlar a incidência dos seus efeitos.

Virgílio, a priori, não descarta o uso da Teoria da Eficácia Indireta, afirmando que, sempre que possível os efeitos dos direitos fundamentais serão sentidos nas relações privadas por meio do material normativo do direito privado, conforme ressaltado alhures (cf. 2.2).

Todavia, surgirão casos em que, seja por omissão, seja por insuficiência legislativa, os Direitos Fundamentais (naquela concepção de princípios) deverão ser aplicados de maneira direta nas relações intersubjetivas. Desta feita, a autonomia privada assume um papel de princípio formal, sendo certo que os direitos fundamentais serão tidos como princípios materiais. Nesse diapasão, enquanto estes tendem a limitar a autonomia privada, esta, na condição de princípio formal desempenha uma função oposta, ou seja, visa garantir o respeito a essa autonomia, mesmo nas hipóteses em que há direitos fundamentais envolvidos.

Aparentemente, um eventual conflito entre estes princípios poderia ser solucionado pela Lei de Colisão que pode ser assim resumida - em uma linguagem um pouco menos formal: o que se perde de um lado deve ser compensado pelo que se ganha do outro. Contudo, na relação autonomia privada $v$. direitos fundamentais a lei de colisão não poderá ser aplicada, isto porque, explica SILVA, "os critérios para um sopesamento no âmbito das relações entre os particulares sob a égide da autonomia privada não relacionam o grau de restrição ao direito fundamental atingido, com a importância da realização da autonomia privada."38

Assim, o caminho então será definir situações em que a autonomia privada - enquanto um princípio formal - deverá ser mais respeitada, e ocasiões em que, tal respeito poderá ser mitigado em face dos direitos fundamentais. Como se pode perceber, não se está em uma análise bidirecional, própria da lei de colisão (portanto, não há que se falar em sopesamento), porém, estamos sim, diante de uma situação valorativa (da autonomia privada).

Surge, então, a necessidade de se elaborar critérios com o escopo de se definir o peso da autonomia privada em cada uma dessas relações que envolvam restrições aos direitos fundamentais. O primeiro deles é a assimetria

\footnotetext{
37 SILVA, Virgílio Afonso da. A constitucionalização do direito: os direitos fundamentais nas relações entre particulares. São Paulo: Malheiros, 2005, p. 146.

38 SILVA, Virgílio Afonso da. A constitucionalização do direito: os direitos fundamentais nas relações entre particulares. São Paulo: Malheiros, 2005, p. 154-155.
} 
das partes envolvidas. Contudo, Virgílio Afonso da SILVA, diferentemente de Daniel SARMENTO, fundamenta a assimetria no grau de autonomia real das partes envolvidas, e não desigualdade material. O chamado grau de autonomia real quer indicar fatores que eventualmente possam existir e que impeçam que uma das partes tome decisões no pleno exercício de sua autonomia. Se estivermos diante de um caso assim, a autonomia deve ter seu peso reduzido em relação ao direito fundamental restringido.

O segundo critério proposto por SILVA é o conjunto: precedência prima facie e intensidade da restrição a direitos. Este mecanismo, de caráter residual, deve ser aplicado na ineficiência da assimetria das partes. Por ele a autonomia privada sempre terá uma precedência prima facie frente aos direitos fundamentais envolvidos. Porém essa precedência poderá ser revertida - ainda que haja assimetria das partes e o real exercício da autonomia privada desde que o peso do princípio formal expressado pela autonomia privada tender a ser menor quanto maior for a intensidade da restrição aos direitos fundamentais envolvidos.

Dessa forma, em apertadíssima síntese, resumimos as principais teorias desenvolvidas pela doutrina brasileira, que se dedicaram à temática. Insta ressaltar que todos os trabalhos analisados são de altíssima qualidade e demonstram a competência de seus autores em construir modelos dotados de grande rigor científico.

Contudo, a tese de Virgílio Afonso da SILVA é, sem dúvida, a que melhor descreve um padrão ou modelo a ser seguido, principalmente pela jurisprudência, pois, em que pese a complexidade dos mecanismos apresentados (herança de seus estudos na Alemanha), o grau de abstração e o caráter universalizante de sua proposta, certamente será de grande valia para a interpretação dos tribunais quando se depararem com os conflitos envolvendo a temática, pois, como afirma o autor "todo modelo é vazio, apenas forma. [...] é um ferramenta de trabalho que ganha corpo com a prática doutrinária e, especialmente, jurisprudencial." ${ }^{39}$

A seguir, vamos analisar o tratamento dado pelo Supremo Tribunal Federal à questão da vinculação dos direitos fundamentais e como a doutrina tem servido de guia para o avanço dos magistrados na consolidação desse hábil instrumento de tutela dos precípuos direitos constitucionais.

3.1. A jurisprudência constitucional da incidência dos Direitos Fundamentais nas relações entre particulares

Como visto no tópico anterior, a doutrina brasileira encontra-se em fase de amadurecimento sobre a temática. Os primeiros trabalhos dedicados integralmente ao assunto consideram nosso paradigma constitucional extremamente propício para o reconhecimento da possibilidade dos Direitos

\footnotetext{
${ }^{39}$ SILVA, Virgílio Afonso da. A constitucionalização do direito: os direitos fundamentais nas relações entre particulares. São Paulo: Malheiros, 2005, p. 176.
} 
Fundamentais se vincularem nas relações entre particulares, e ainda, propugnam que a incidência de seus efeitos se dê de maneira direta.

Nesta esteira, a jurisprudência constitucional brasileira também mostra sinais de progresso, pois se observarmos os últimos quinze anos de trabalho do Supremo Tribunal Federal, notaremos, claramente, uma escala evolutiva em seus julgados. Os primeiros cases enfrentados pelos STF demonstravam uma aplicação assistemática, precedidos de uma fundamentação teórica muito vaga. Certamente esse cenário refletia a parca produção doutrinária a respeito da temática, não favorecendo maiores lastros para a atuação da Corte.

Nesse sentido, na ponta desta escala evolutiva podemos citar o RE 158.215/RS de relatoria do Ministro Marco AURÉLIO julgado em abril de 1996, cuja ementa transcrevemos:

DEFESA - DEVIDO PROCESSO LEGAL - INCISO LV DO ROL DAS GARANTIAS CONSTITUCIONAIS - EXAME - LEGISLAÇÃO COMUM. A intangibilidade do preceito constitucional assegurador do devido processo legal direciona ao exame da legislação comum. Daí a insubsistência da óptica segundo a qual a violência à Carta Política da República, suficiente a ensejar o conhecimento de extraordinário, há de ser direta e frontal. Caso a caso, compete ao Supremo Tribunal Federal exercer crivo sobre a matéria, distinguindo os recursos protelatórios daqueles em que versada, com procedência, a transgressão a texto constitucional, muito embora torne-se necessário, até mesmo, partir-se do que previsto na legislação comum. Entendimento diverso implica relegar à inocuidade dois princípios básicos em um Estado Democrático de Direito - o da legalidade e do devido processo legal, com a garantia da ampla defesa, sempre a pressuporem a consideração de normas estritamente legais. COOPERATIVA - EXCLUSÃO DE ASSOCIADO CARÁTER PUNITIVO - DEVIDO PROCESSO LEGAL. Na hipótese de exclusão de associado decorrente de conduta contrária aos estatutos, impõe-se a observância ao devido processo legal, viabilizado o exercício amplo da defesa. Simples desafio do associado à assembleia geral, no que toca à exclusão, não é de molde a atrair adoção de processo sumário. Observância obrigatória do próprio estatuto da cooperativa. (STF - $2^{\mathrm{a}}$ Turma. Recurso Extraordinário $\mathrm{n}^{\circ}$ 158.215-RS. Relator: Ministro Marco Aurélio. Recorrentes: Ayrton da Silva Capaverde e outros. Recorrido: Cooperativa Mista São Luiz LTDA. j. 30.04.1996)

O caso em tela versava sobre a expulsão de alguns sócios, realizada sem a observância das regras do estatuto e sem a possibilidade de defesa. A Cooperativa alegou que a atitude foi tomada em face do desafio lançado pelos membros expulsos frente a imprensa local. Diante dessa situação, o Ministro Marco AURÉLIO, sem tangenciar as teorias que tratam da vinculação dos Direitos Fundamentais as relações privadas, reconheceu que atitude da Cooperativa - em expulsar os sócios como caráter punitivo - feria frontalmente $\mathrm{o}$ inc. $\mathrm{LV}$ do art. $5^{\circ} \mathrm{da} \mathrm{CF}$, pois como asseverou em seu voto: 
A exaltação de ânimos não é de molde a afastar a incidência do preceito constitucional assegurador da plenitude da defesa nos processos em geral. Mais do que nunca, diante do clima reinante, incumbia à Cooperativa, uma vez instaurado o processo, dar aos acusados a oportunidade de defenderem-se e não excluí-los sumariamente do quadro de associados. ${ }^{40}$

Nesse sentido, o Ministro conheceu do Recurso Extraordinário e the deu provimento garantindo assim o direito fundamental daqueles sócios, que havia sido violado.

Outro acórdão, do início desta linha evolutiva, que merece relevo é o RE 161.243/DF, julgado em outubro de 1996, sob relatoria do então Ministro Carlos Mário VELLOSO, no qual um trabalhador brasileiro da companhia aérea francesa Air France, com fundamento no art. $5^{\circ}$ da CF de 1988, pedia o reconhecimento de direitos trabalhistas assegurados no Estatuto dos Funcionários da empresa, mas que beneficiava somente os empregados de nacionalidade francesa. O STF mais uma vez reconheceu - sem maiores ilações teóricas sobre a vinculação dos direitos fundamentais entre particulares - o direito pleiteado, lavrando-se a seguinte ementa:

\begin{abstract}
CONSTITUCIONAL. TRABALHO. PRINCÍPIO DA IGUALDADE. TRABALHADOR BRASILEIRO EMPREGADO DE EMPRESA ESTRANGEIRA: ESTATUTOS DO PESSOAL DESTA: APLICABILIDADE AO TRABALHADOR ESTRANGEIRO E AO TRABALHADOR BRASILEIRO. C.F., 1967, art. 153, § 10; C.F., 1988, art. 5, caput. I. - Ao recorrente, por não ser francês, não obstante trabalhar para a empresa francesa, no Brasil, não foi aplicado o Estatuto do Pessoal da Empresa, que concede vantagens aos empregados, cuja aplicabilidade seria restrita ao empregado de nacionalidade francesa. Ofensa ao princípio da igualdade: C.F., 1967, art. 153, § 10; C.F., 1988, art. 50, caput). II. - A discriminação que se baseia em atributo, qualidade, nota intrínseca ou extrínseca do indivíduo, como o sexo, a raça, a nacionalidade, o credo religioso, etc., é inconstitucional. Precedente do STF: Ag 110.846(AgRg)-PR, Célio Borja, RTJ 119/465. III. - Fatores que autorizariam a desigualização não ocorrentes no caso. IV. - R.E. conhecido e provido. (STF - 2a Turma. Recurso Extraordinário $n^{\circ}$ 161.243-DF. Relator: Ministro Carlos Mário Velloso. Recorrente: Joseph Halfin. Recorrida: Compagnie Nationale Air France. j. 29.10.1996.)
\end{abstract}

Por fim, trazemos a baila um julgado paradigmático, no qual a referência a eficácia dos direitos fundamentais foi explícita e citada por diversos ministros durante o julgamento. Podemos concluir que, por se tratar de um acórdão atualíssimo, pois data de 2005, os atuais Ministros se sentiram avalizados

${ }^{40}$ BRASIL. Supremo Tribunal Federal. $2^{\mathrm{a}}$ Turma. Recurso Extraordinário $n^{\circ}$ 158.215-RS. Relator: Ministro Marco Aurélio. Recorrentes: Ayrton da Silva Capaverde e outros. Recorrido: Cooperativa Mista São Luiz LTDA. J. 30.04.1996. 
pelos trabalhos doutrinários e não se intimidaram a fazer referências diretas às várias teses que cuidam da vinculação dos Direitos Fundamentais nas relações privadas. Trata-se do RE 201.819/RJ de relatoria original da Ministra Ellen GRACIE, e que para surpresa de muitos e acalento dos defensores da Teoria dos Efeitos Direitos, consignou em sua ementa a filiação a esta tese:

SOCIEDADE CIVIL SEM FINS LUCRATIVOS. UNIÃO BRASILEIRA DE COMPOSITORES. EXCLUSÃO DE SÓCIO SEM GARANTIA DA AMPLA DEFESA E DO CONTRADITÓRIO. EFICÁCIA DOS DIREITOS FUNDAMENTAIS NAS RELAÇÕES PRIVADAS. RECURSO DESPROVIDO. I. EFICÁCIA DOS DIREITOS FUNDAMENTAIS NAS RELAÇÕES PRIVADAS. As violações a direitos fundamentais não ocorrem somente no âmbito das relações entre o cidadão e o Estado, mas igualmente nas relações travadas entre pessoas físicas e jurídicas de direito privado. Assim, os direitos fundamentais assegurados pela Constituição vinculam diretamente não apenas os poderes públicos, estando direcionados também à proteção dos particulares em face dos poderes privados. II. OS PRINCÍPIOS CONSTITUCIONAIS COMO LIMITES À AUTONOMIA PRIVADA DAS ASSOCIAÇÕES. A ordem jurídico-constitucional brasileira não conferiu a qualquer associação civil a possibilidade de agir à revelia dos princípios inscritos nas leis e, em especial, dos postulados que têm por fundamento direto o próprio texto da Constituição da República, notadamente em tema de proteção às liberdades e garantias fundamentais. O espaço de autonomia privada garantido pela Constituição às associações não está imune à incidência dos princípios constitucionais que asseguram o respeito aos direitos fundamentais de seus associados. A autonomia privada, que encontra claras limitações de ordem jurídica, não pode ser exercida em detrimento ou com desrespeito aos direitos e garantias de terceiros, especialmente aqueles positivados em sede constitucional, pois a autonomia da vontade não confere aos particulares, no domínio de sua incidência e atuação, o poder de transgredir ou de ignorar as restrições postas e definidas pela própria Constituição, cuja eficácia e força normativa também se impõem, aos particulares, no âmbito de suas relações privadas, em tema de liberdades fundamentais. III. SOCIEDADE CIVIL SEM FINS LUCR ATIVOS. ENTIDADE QUE INTEGRA ESPAÇO PÚBLICO, AINDA QUE NÃO-ESTATAL. ATIVIDADE DE CARÁTER PÚBLICO. EXCLUSÃO DE SÓCIO SEM GARANTIA DO DEVIDO PROCESSO LEGAL. APLICAÇÃO DIRETA DOS DIREITOS FUNDAMENTAIS À AMPLA DEFESA E AO CONTRADITÓRIO. As associações privadas que exercem função predominante em determinado âmbito econômico e/ou social, mantendo seus associados em relações de dependência econômica e/ou social, integram o que se pode denominar de espaço público, ainda que não-estatal. A União Brasileira de Compositores - UBC, sociedade civil sem fins lucrativos, integra a estrutura do ECAD e, portanto, assume posição privilegiada para determinar a extensão do gozo e fruição dos direitos autorais de seus associados. A exclusão de sócio do quadro social da UBC, sem 
qualquer garantia de ampla defesa, do contraditório, ou do devido processo constitucional, onera consideravelmente o recorrido, o qual fica impossibilitado de perceber os direitos autorais relativos à execução de suas obras. A vedação das garantias constitucionais do devido processo legal acaba por restringir a própria liberdade de exercício profissional do sócio. O caráter público da atividade exercida pela sociedade e a dependência do vínculo associativo para o exercício profissional de seus sócios legitimam, no caso concreto, a aplicação direta dos direitos fundamentais concernentes ao devido processo legal, ao contraditório e à ampla defesa (art. 5º, LIV e LV, CF/88). IV. RECURSO EXTRAORDINÁRIO DESPROVIDO. (STF - $2^{\mathrm{a}}$ Turma. Recurso Extraordinário no 201.819/RJ. Relatora Originária: Ministra Ellen Gracie. Relator para o acórdão: Ministro Gilmar Mendes. Recorrente: União Brasileira de Compositores - UBC. Recorrido: Arthur Rodrigues Villarinho. j. 11.10.2005) grifo nosso.

O caso em tela é faticamente muito semelhante ao primeiro julgado que trouxemos no início desse tópico. Trata-se da exclusão de um sócio da União Brasileira de Compositores sem a observância do direito fundamental insculpido no inc. LV do art. $5^{\circ}$ da Constituição Federal. Todavia, a diferença está na ampla discussão travada no STF e a aprofundada fundamentação realizada pelos ministros na defesa das posições assumidas.

O ministro Gilmar MENDES em seu Voto-Vista teceu longos e profícuos comentários sobre a atual situação do tema em sede do Direito Comparado. Por fim, em sua análise quanto ao caso concreto, definiu que se tratava, na espécie, de se reconhecer de maneira direta, os efeitos dos direitos fundamentais na relação travada entre o sócio expulso sem o devido processo legal. Em um voto brilhante e amparado por grande conteúdo doutrinário, o Ministro Gilmar MENDES inaugurou certamente uma nova fase no STF alargando de maneira excepcional a possibilidade de uma efetiva tutela dos Direitos Fundamentais. Sua posição foi acompanhada pelos Ministros Joaquim BARBOSA e Celso de MELLO.

A ministra Ellen GRACIE e o ministro Carlos VELLOSO foram votos vencidos e defendiam a ausência de violação do princípio do devido processo legal, pois foi obedecido o procedimento de exclusão fixado no Estatuto da Recorrente. Ademais, segundo a Ministra, o caso de expulsão de sócios de uma entidade privada resolve-se a partir das regras do estatuto social e da legislação civil em vigor, não tendo que se falar em observância do princípio constitucional do inc. LV do art. $5^{\circ}$ da CF.

À guisa de conclusão, podemos afirmar que com este passo inicial da jurisprudência associado ao intenso desenvolvimento doutrinário e acadêmico do assunto, em breve estaremos diante de um cenário consolidado de reconhecimento da vinculação dos Direitos Fundamentais nas relações interpessoais, bem como de um modelo capaz de regular os efeitos dessa incidência constitucional. 


\section{CONCLUSÃO}

O intróito desse trabalho trouxe a lume o novo fenômeno pelo qual passa grande parte dos ordenamentos jurídicos hodiernamente. Trata-se da chamada Constitucionalização do Direito, realidade inegável do paradigma constitucional vigente e cujo principal efeito dentro do Direito Privado é a possibilidade de se admitir a vinculação (que pode ser direta ou indireta, conforme se demonstrou) dos Direitos Fundamentais no âmbito das relações pessoais.

Assim, ao longo do trabalho, a vinculação dos particulares aos Direitos Fundamentais mostrou-se como sendo a principal tese de nossa argumentação, sendo certo que a regulação dos seus efeitos é o maior ponto de conflito para aqueles que se dedicaram ao estudo desta temática.

Os esforços empreendidos pela dogmática constitucional, visando à construção de modelos que pudessem regular a contento os efeitos dessa incidência, tomaram conta de teóricos da Europa (em especial na Alemanha, nascedouro das primeiras teses) e avançando sobre o Atlântico, chegando a discussão nos Estados Unidos e nos demais países da América do Sul.

$\mathrm{O}$ modelo dos Efeitos Indiretos sagrou-se como o mais adequado à realidade jurídica (atendendo os detalhes de sua ordem constitucional) e social da Alemanha, posto que atende perfeitamente as demandas envolvendo a temática da vinculação. Em que pese esse standard obrigar o intérprete a se valer de conceitos muito flexíveis e construções teóricas ainda mais complexas, o que daria ensejo a decisões muito subjetivas, o Tribunal Constitucional Alemão tem, desde o caso Lüth, desenvolvido uma farta jurisprudência dotada de muita parcimônia e equidade.

Já a tese da Eficácia Direta, predominante em grande parte dos países europeus (Portugal, Espanha, Itália etc.), é a que mais desperta adeptos na doutrina brasileira. De fato, concordamos com Daniel SARMENTO, quando ele afirma, peremptoriamente, ser este o modelo que melhor se enquadraria para a nossa realidade social, pois vivemos imersos em uma sociedade desigual que clama a efetivação de direitos fundamentais, muitas vezes mínimos para se atender o princípio constitucional da vida com dignidade. Isto representa, sobremaneira, a situação descrita várias vezes por nós: hodiernamente o Estado perdeu a posição de único violador dos direitos fundamentais, de maneira que, a transgressão de tais direitos parte de todos os lados e de vários atores sociais (na esfera familiar, contratual, etc). Este fenômeno dentro da sociedade brasileira é, certamente, ainda mais acentuado.

Desse modo, a busca por um modelo com o escopo de instrumentalizar uma teoria que tem como fim último, a tutela efetiva dos Direitos Fundamentais é, estreme de dúvidas, algo muito salutar dentro da nossa ordem jurídica que reverbera os anseios de nossa ordem social.

Nesse sentido, afirmamos, ao longo do trabalho que a tese desenvolvida por Virgílio Afonso da SILVA seria a mais consentânea dentre as elaboradas até o momento, pois a presença de muitos mecanismos generalizantes 
pode diminuir consideravelmente a margem de subjetivismo do julgador e fazer prevalecer assim uma situação justa, pois a defesa dos direitos fundamentais, muitas vezes deve prevalecer em face da autonomia privada, que como afirmado por SILVA, está muito suscetível a engodos de todos os tipos.

Ressaltamos, ainda, os primeiros passos do Supremo Tribunal Federal no reconhecimento da aplicabilidade direta dos Direitos Fundamentais em sede das relações privadas. O RE 201.819/RJ é um verdadeiro marco na aceitação expressa dessa tese e abre possibilidades reais de tutela dos Direitos Fundamentais.

Nessa esteira, com a sinalização positiva da mais alta Corte do nosso Judiciário atrelado ao fato do nosso sistema de controle de constitucionalidade ser difuso, projetamos que mais lides possam ser demandas visando a tutela dos direitos fundamentais e, dessa forma, devemos aguardar o trabalho dos Tribunais e esperar que estes, ainda que de forma coercitiva, reduzam as iniquidades existentes nas relações sociais.

Assim, diante de todas as linhas aqui redigidas a conclusão deste pequeno ensaio se mostra única, ou seja, a vinculação dos direitos fundamentais é uma realidade, admitida até mesmo pelo STF e que a busca pelo aperfeiçoamento da construção dogmática de um modelo tipicamente brasileiro deve ser um esforço de todos aqueles que acreditam que o Direito pode realmente transformar a realidade vigente em uma sociedade livre, justa e solidária, como preconizam os objetivos constitucionais do art. $3^{\circ}$ da CF. Acreditamos, que nossa modesta contribuição, ainda que tenha fica em um plano críticodescritivo, já pode se somar as demais colaborações até hoje realizadas.

\section{REFERÊNCIAS}

ALEXY, Robert. Teoria dos Direitos Fundamentais. São Paulo: Malheiros, 2008.

BARROSO, Luís Roberto. Curso de direito constitucional contemporâneo: os conceitos fundamentais e a construção do novo modelo. São Paulo: Saraiva, 2009.

BILBAO UBILLOS, Juan Maria. ¿En qué medida vinculan a los particulares los derechos fundamentales?. In: SARLET, Ingo Wolfgang (org). Constituição, Direitos Fundamentais e Direito Privado. 2. ed. Porto Alegre: Livraria do Advogado, 2006.

BON, Pierre. Table ronde: le cas de Espagne. In: VERPEAUX, Michel (org.). Code civil et constitution(s). Paris: Economica, 2005.

BRASIL. Supremo Tribunal Federal. Jurisprudência. Disponível em:

$<$ http://www.stf.jus.br/portal/jurisprudencia/pesquisarJurisprudencia.asp >. Acesso em: 2009.

CANARIS, Claus-Wilhelm. A influência dos direitos fundamentais sobre o direito privado na Alemanha. In: SARLET, Ingo Wolfgang (org). Constituição, Direitos Fundamentais e Direito Privado. 2. ed. Porto Alegre: Livraria do Advogado, 2006.

Direitos Fundamentais e Direito Privado. Coimbra: Almedina. 2003.

CANOTILHO, José Joaquim Gomes. Direito Constitucional e Teoria da Constituição. 7. ed. Coimbra: Almedina, 2003. 
CANOTILHO, José Joaquim Gomes; MOREIRA, Vital. Constituição da República Portuguesa Anotada. São Paulo: RT, 2007.

COURTIS, Christian. La eficacia de los derechos humanos en las relaciones entre particulares. In: SARLET, Ingo Wolfgang (org). Constituição, Direitos Fundamentais e Direito Privado. 2. ed. Porto Alegre: Livraria do Advogado, 2006.

DÜRIG, Günter. Grundrechte und Zivilrechtsprechung. In: MAUNZ, Theodor (org.). Vom bonner grundgesetz sur gezamtdeustschen verfassung: festschrift zum 75. Geburtstag von Hans Nawiasky. Munique: Isar, 1956.

FACCHINI NETO, Eugênio. Reflexões histórico-evolutivas sobre a constitucionalização do direito privado. In: SARLET, Ingo Wolfgang (org.). Constituição, Direitos Fundamentais e Direito Privado. 2. ed. Porto Alegre: Livraria do Advogado, 2006.

FAVOREU, Louis. La constitutionnalisation du droit. In: MATHIEU, Bertrend; VERPEAUX, Michel (org.). La Constitutionnalisation des Branches du Droit. Paris: Economica, 1998.

. La constitutionnalisation du droit. In: AUBY, Jean-Bernard (et al.). L'unité du droit: mélange en hommage à Roland Drago. Paris: Economica, 1996.

GARCíA TORRES, Jesús; JIMÉNEZ-BLANCO, Antonio. Derechos Fundamentales y Relaciones entre Particulares. Madrid, Civitas, 1986.

NIPPERDEY, Hans Carl. Grundrechte und privarecht. In. NIPPERDEY, Hans Carl (org.). Festschrift für Erich Molitor zum 75. Geburtstag. Munique: C.H. Beck, 1962.

PERLINGIERI, Pietro. Perfis do direito civil: introdução ao direito civil constitucional. 3. ed. Rio de Janeiro: Renovar, 2007.

SAMPAIO, José Adércio Leite. Mito e história da constituição: prenúncios sobre a constitucionalização do direito. In: SOUZA NETO, Cláudio Pereira; SARMENTO, Daniel. A constitucionalização do direito: fundamentos teóricos e aplicações específicas. Rio de Janeiro: Lumen Juris, 2007.

SARLET, Ingo Wolfgang (org). Constituição, Direitos Fundamentais e Direito Privado. 2. ed. Porto Alegre: Livraria do Advogado, 2006.

SARMENTO, Daniel. Direitos Fundamentais e Relações Privadas. 2. ed. Rio de Janeiro: Lumen Juris, 2008.

SILVA, Virgílio Afonso da. A constitucionalização do direito: os direitos fundamentais nas relações entre particulares. São Paulo: Malheiros, 2005.

STEINMETZ, Wilson. Vinculação dos Particulares a Direitos Fundamentais. São Paulo: Malheiros, 2004.

VERDU, Pablo Lucas. O sentimento constitucional: aproximação ao estudo do sentir constitucional como modo de integração política. Rio de Janeiro: Forense, 2004. 